\title{
PENGARUH KOMPOSISI HERBAL DALAM MINUMAN TEH HIJAU GAMBUNG HERBAL TERHADAP HAMBATAN $\alpha$-GLUKOSIDASE
}

\author{
Megawati, Hani Mulyani, Minarti, Teni Ernawati, Akhmad Darmawan \\ Research Center for Chemistry, Indonesian Institute of Sciences, \\ Kawasan PUSPIPTEK Serpong, Tangerang Selatan, Banten, Indonesia \\ Email: megarafandi@gmail.com
}

\begin{abstract}
The aim of this study is to make a formula of green tea that is enriched by other herbs. Green tea drinks are made using the basic ingredients of gambung (THG) green tea enriched with sapodilla leaves (Manilkara zapota $(A w)$ bay leaves (Syzygium polyanthum (Am), Artocarpus communis (Un) breadfruit leaves, and cinnamon leaves (Cinnamomum verum $(K))$. The composition of gambung herbal green tea is made by reference to the antidiabetic activity of each herb. All the samples were tested for inhibition of a-glucosidase enzymes and toxicity using the lethality test method for brine shrimp. All samples showed good inhibition of the a-glucosidase enzyme barriers of gamboeng green tea (THG) $82.05 \%$, sapodilla leaves (Aw) $97.81 \%$, breadfruit leaves (Un) $73.34 \%$, bay leaves (Am) $93.80 \%$, cinnamon leaves $(K) 91.24 \%$. The inhibition value of $\alpha$-glucoside enzymes in the formulation of gamboeng herbal green tea drinks: $96.203 \%$ (GKUn) is higher when compared to the GKAm formula (94.78\%) and GKAw (62.487\%).
\end{abstract}

Key words: $\alpha$-glukosidase, teh hijau gamboeng, brine shrimp lethality

\section{PENDAHULUAN}

Teh hijau merupakan teh yang dibuat dari pucuk daun tanaman teh (Camellia sinensis) yang mengalami proses pengukusan/pemanasan dengan menggunakan uap (steaming) untuk mencegah terjadinya oksidasi enzimatis oleh enzim polifenol oksidase sehingga teh hijau memiliki kandungan katekin lebih tinggi dibandingkan jenis teh lainnya. Teh hijau terkenal terutama di negara-negara Asia. Teh hijau telah dilaporkan memiliki berbagai bioaktivitas seperti: anti-inflamatori, anti-proliferasi, dan antiatherosklerotis, antimikroba, anti kanker, antioksidan dan mengurangi kadar gula darah. ${ }^{1}$

Telah dilaporkan bahwa polifenol pada teh hijau dapat 
Pengaruh komposisi herbal dalam minuman teh hijau gambung herbal terhadap hambatan $\alpha$ glukosidase

menghambat enzim pertumbuhan kanker dan menurunkan obesitas. Manfaat potensial dari mengkonsumsi teh bagi kesehatan terkait dengan sifat antioksidan polifenol teh. Polifenol adalah antioksidan yang sangat kuat, salah satu fungsinya dapat mengatasi radikal bebas yang merupakan molekul sangat tidak stabil yang berada dalam tubuh. Polifenol pada teh, khususnya katekin dan theaflavin, dapat menjalankan aktivitas antioksidan terutama melalui pengikatan radikal bebas, ion logam transisi kelat, dan modulasi oksidan atau antioksidan enzim untuk gen. ${ }^{2}$

Hal ini menjadikan ekstrak teh hijau digunakan sebagai suplemen, nutrasetikal, dan pangan fungsional. ${ }^{3}$ Daun teh mengandung $30-40 \%$ polifenol yang sebagian besar senyawa utamanya adalah katekin, kafein dan tannin serta lebih dari 400 senyawa kimia yang terkandung di dalam the. ${ }^{4}$ Enam kelompok utama katekin adalah epicatechin (EC), epigallocatechin (EGC), epicatechin gallat (ECG), epigallocatechin gallat (EGCG), gallocatechin (GC), gallocatechin gallat (GCG). Yashin menyebutkan bahwa epigallocatechin gallat (EGCG) merupakan katekin paling dominan dalam teh hijau yang dapat mencapai hingga $50 \%$ dari berat katekin. ${ }^{16}$ (Rohdiana et al., 2012) menyatakan bahwa aktivitas EGCG menyumbang $32 \%$ dari potensi antioksidan the. 5,6

Karakteristik dan kualitas daun teh tergantung pada banyak faktor seperti lingkungan (kelembaban, paparan matahari, ketinggian, dan komposisi tanah), umur teh (pemetikan, jumlah, mekanis), teknik pengolahan (tingkat fermentasi) dan metode penyeduhan. ${ }^{7,8}$

Proses penyeduhan adalah proses pemisahan komponen dengan menggunakan pelarut air. Dalam proses penyeduhan perlu diperhatikan beberapa faktor, seperti waktu dan suhu penyeduhan. Proses penyeduhan tersebut berfungsi mempertahankan kualitas senyawa kimia yang diinginkan. Untuk meningkatkan fungsi dari teh hijau gambung dalam hambatannya terhadap enzim $\alpha$ glukosidase, maka dilakukan kombinasi formula dengan tanaman daun sukun, daun salam, daun sawo dan daun kayumanis. Berdasarkan literature daun sukun (Artocarpus communis) memiliki khasiat sebagai antidiabetes ${ }^{9}$, daun kayumanis (Cinnamomum verum) berfungsi sebagai antidiabetes ${ }^{10}$, daun salam (Syzygium polyanthum) memiliki 
Pengaruh komposisi herbal dalam minuman teh hijau gambung herbal terhadap hambatan $\alpha$ glukosidase

khasiat antioksidan yang cukup tinggi ${ }^{11}$ dan daun sawo (Manilkara zapota) dilaporkan memiliki aktivitas sebagai anti diabetes. ${ }^{12}$

Penelitian ini bertujuan untuk membuat formulasi teh hijau gamboeng (THG) herbal yang diperkaya dengan sukun (Artocarpus communis (Sk)), salam (Syzygium polyanthum (SI)), daun kayumanis (Cinnamomum verum $(\mathrm{K})$ ), dan daun sawo (Manilkara zapota (Sw)) yang memiliki aktivitas sebagai antidiabetes.

\section{METODE PENELITIAN \\ Materi}

Teh hijau gambung dari PPTK, daun sukun (Artocarpus communis $(U n)$ ), daun salam (Syzygium polyanthum $(\mathrm{Am})$ ), daun kayumanis (Cinnamomum verum $(\mathrm{K})$ ), dan daun sawo (Manilkara zapota (Aw)) yang di ambil dari daerah Bogor, Indonesia. Air, kertas saring, a-Glukosidase Type I: dari yeast Saccharomyces cerevisiae (EC 3.2.1.20), bovine serum albumin dan $p$-nitrophenyl- $\alpha$ - $D$-glucopyranoside ( $p-N P G)$ subtrat $\alpha$-glukosidasedari Wako Pure Chemical Industries, Ltd. (Osaka, Japan), Artemia salina Leach.

\section{Prosedur Kerja}

\section{Persiapan Sampel}

Pemisahan daun dari tangkai yang busuk, pencucian daun herbal, penggilingan semua daun herbal dengan blander untuk semua sampel teh hijau gamboeng, daun sukun (Artocarpus communis (Un)), daun salam (Syzygium polyanthum (Am)), daun kayumanis (Cinnamomum verum (K)), dan daun sawo (Manilkara zapota $(A w))$. Masing masing herbal disiapkan untuk pengujian aktivitas antidiabetes menggunakan konsentrasi 10\% (10 gram dalam $100 \mathrm{~mL}$ air seduhan), $5 \%$ (5 gram dalam $100 \mathrm{~mL}$ air seduhan), $2 \%$ (2 gram dalam $100 \mathrm{~mL}$ air seduhan) and $1 \%$ (1 gram dalam $100 \mathrm{~mL}$ air seduhan) dan disiapkan untuk formulasi minuman teh hijau gambung herbal.

\section{Formulasi}

Langkah pertama preparasi, proses maserasi dari herbal. 1 gram teh hijau gambung (THG), daun sukun (Artocarpus communis (Un)), daun Salam (Syzygium polyanthum (Am)), Daun Kayumanis (Cinnamomum verum (K)), dan daun Sawo (Manilkara zapota $(\mathrm{Aw}))$ diseduh dengan air panas pada suhu $70-90^{\circ} \mathrm{C}$ selama $10-15$ menit. Pembuatan formulasi fortifikasi ekstrak dari $100 \mu \mathrm{L}$ dari masing-masing herbal di campur sehingga didapatkan formula THG-Un-K, THG-Aw-K, dan THG-Aw$\mathrm{K}$. 
Pengaruh komposisi herbal dalam minuman teh hijau gambung herbal terhadap hambatan $\alpha$ glukosidase

\section{Uji Hambatan a-glukosidase}

Uji aktivitas hambatan terhadap enzim a-glukosidase menggunakan metoda yang dikembangkan oleh Sancheti dengan modifikasi ${ }^{13}: 0,5$ gram a-glukosidase (Sigma, St. Louis, MO, USA) ditambahkan dalam $10 \mathrm{~mL}$ of $0,9 \%$ air $(100: 1 \quad w / v)$. Dilakukan sonikasi pada suhu $4^{\circ} \mathrm{C}$ selama 30 detik, dan disentrifus $\left(30 \mathrm{~min}, 4^{\circ} \mathrm{C}\right)$. Supernatan disiapkan untuk pengujian. Lima mikroliter larutan sampel (50-200 $\mu \mathrm{g} / \mathrm{mL}$ ) diinkubasi dengan penambahan $465 \mu \mathrm{L}$ dalam $0.1 \mathrm{M}$ phosphate buffer $(\mathrm{pH} 7,0)$ dan $250 \mu \mathrm{L}$ dalam 5 mMp-NPG. Larutan dalam 0,1 $M$ phosphate buffer $(\mathrm{pH} 7,0)$, diinkubasi pada suhu $37^{\circ} \mathrm{C}$ selama $5 \mathrm{~min}$. Kemudian diinkubasi kembali setelah penambahan $150 \mu \mathrm{L}$ a-glukosidase. Larutan ditambahkan 0,2 $\mathrm{M} \mathrm{Na}_{2} \mathrm{CO}_{3}$ untuk menghentikan reaksi. Absorban di ukur pada $\lambda 400$ nm. Blanko dipreparasi sama dengan sampel kecuali penambahan enzim, diganti dengan $150 \mu \mathrm{L}$ of phosphate buffer.
Analisa dilakukan dengan pengulangan tiga kali. Persen inhibisi $\alpha$-glukosidase dihitung dengan rumus:

$\%$ Inhibition $=\left[1-\left(\frac{A s}{A 0}\right)\right] \times 100$

Dimana, A0 adalah absorban blanko dan As adalah absorban sampel. Nilai $\mathrm{IC}_{50}$ dihitung dari rata-rata nilai inhibisi dengan analisis regresi liniar.

Toksisitas dengan metoda Brine Shrimp Lethality Assay (BSLA)

Setiap seduhan masing masing ekstrak herbal dan semua formulasi teh hijau gamboeng herbal di uji aktivitas toksisitas menggunakan brine shrimpdikembangkan dari meyer yang sudah di modifikasi. ${ }^{14}$ Dipersiapkan sampel dengan konsentrasi awal seduhan. Sebanyak 10 larva udang artemia dipersiapkan selama $2 \times 24$ jam, dan setelah sampel dimasukkan kedalam wall plate, dihitung jumlah udang yang mati setelah 1×24 jam. Pengujian dilakukan sebanyak minimal 3 kali pengulangan. 
Pengaruh komposisi herbal dalam minuman teh hijau gambung herbal terhadap hambatan $\alpha$ glukosidase

\section{HASIL PENELITIAN}

Tabel 1. Nilai hambatan $\alpha$-glukosidase dari teh hijau gamboeng (THG) dan herbal lainnya dan fortifikasinya.

\begin{tabular}{|c|c|c|}
\hline Sampel & $\begin{array}{c}\text { Konsentrasi sampel dalam \% } \\
*(g / \text { vol seduhan })\end{array}$ & $\%$ inhibisi \\
\hline EGCG & & 89,00 \\
\hline \multirow{4}{*}{ Teh Hijau Gamboeng (THG) } & $10 \%$ & 82,05 \\
\hline & $5 \%$ & 55,33 \\
\hline & $2 \%$ & 55,43 \\
\hline & $1 \%$ & 47,31 \\
\hline \multirow{4}{*}{ Daun Kayumanis (K) } & $10 \%$ & 91,24 \\
\hline & $5 \%$ & 19,86 \\
\hline & $2 \%$ & 18,83 \\
\hline & $1 \%$ & 90,11 \\
\hline \multirow{4}{*}{ Daun Salam ( Am) } & $10 \%$ & 93,80 \\
\hline & $5 \%$ & 95,55 \\
\hline & $2 \%$ & 94,05 \\
\hline & $1 \%$ & 93,00 \\
\hline \multirow{4}{*}{ Daun Sukun (Un) } & $10 \%$ & 73,34 \\
\hline & $5 \%$ & 45,56 \\
\hline & $2 \%$ & 51,27 \\
\hline & $1 \%$ & 57,98 \\
\hline \multirow{4}{*}{ Daun Sawo (Aw) } & $10 \%$ & 97,81 \\
\hline & $5 \%$ & 99,90 \\
\hline & $2 \%$ & 90,81 \\
\hline & $1 \%$ & 94,29 \\
\hline THG-Am-K & $1 \%$ & 94,78 \\
\hline THG-Aw-K & $1 \%$ & 62,48 \\
\hline THG-Un-K & $1 \%$ & 96,29 \\
\hline
\end{tabular}

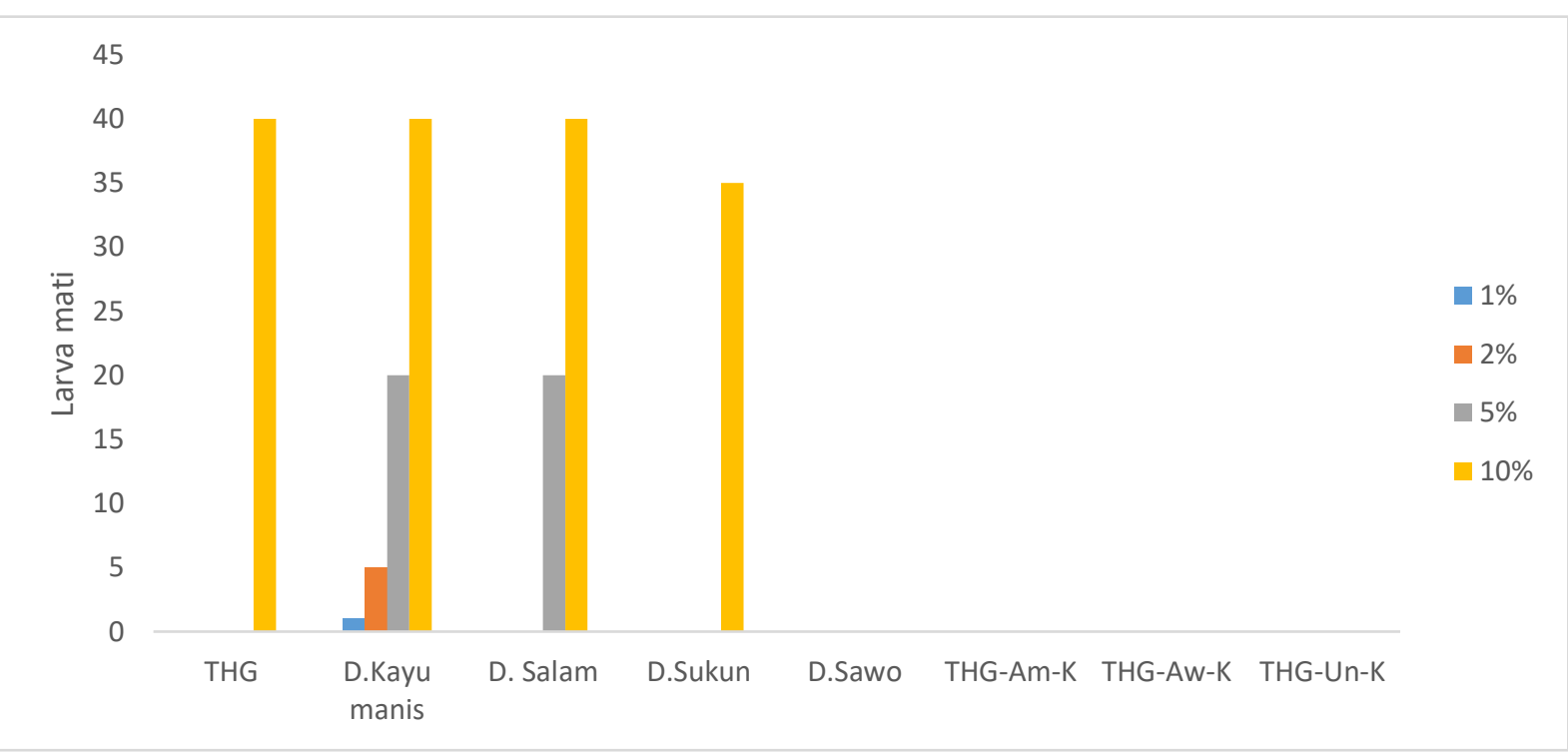

Gambar 1. Pengaruh konsentrasi seduhan herbal terhadap kematian larva udang. 
Pengaruh komposisi herbal dalam minuman teh hijau gambung herbal terhadap hambatan $\alpha$ glukosidase

\section{PEMBAHASAN}

Dari hasil penelitian aktivitas antidiabetes masing masing herbal yang diseduh dengan konsentrasi seduhan $1 \%, 2 \%, 5 \%$ and $10 \%$ selama 10-15 menit, pada suhu air $70-90^{\circ} \mathrm{C}$ diperoleh nilai hambatan terhadap enzim a-glukosidase yang dapat dilihat pada Tabel 1. Senyawa aktif dari masing-masing ekstrak akan menghambat enzim a-glukosidase dalam menghidrolisis carbohydrat komplek, sehingga mengurangi daya serap dari glukosa yang berguna dalam mengurangi glukosa darah paskaprandial dalam mengobati kondisi prediabetik. Dalam penelitian ini akan di teliti daya hambat dari seduhan masing-masing herbal dalam menghambat enzim a-glukosidase.

Uji aktivitas antidiabet terhadap herbal yang dilakukan pada seduhan herbal dapat menghasilkan hambatan terbesar pada konsentrasi seduhan $10 \%$ pada ekstrak daun teh hijau gamboeng, daun kayumanis, dan daun sukun dengan nilai $82,05 \%$, $91,24 \%$ dan $73,34 \%$, pada daun salam dan daun sawo pada konsentrasi seduhan $5 \%$ dengan nilai $95,55 \%$ dan $99,90 \%$. Sedangkan pada konsentrasi $1 \%$ memiliki nilai hambatan dari THG, daun kayumanis, daun salam, daun sukun dan daun sawo adalah $47,31 \%, 90,11 \%, 93 \%, 57,98 \%$ dan $94,29 \%$. Sedangkan pada formulanya, kita menggunakan konsentrasi $1 \%$ dikarenakan setelah dilakukan uji praklinis yang aman pada konsentrasi $1 \%$, dapat dilihat dari Gambar 1.

Pengujian aktivitas hambatan $\alpha$ glukosidase terhadap formulasi teh hijau gamboeng herbal (THG-Un-K, THG-Aw-K, dan THG-Am-K.) telah dilakukan. Hasil pengujian diperoleh bahwa formula yang mengandung daun sukun (THG-Un-K) dengan nilai hambatan 96,29\%. Aktivitas antidiabetes yang cukup tinggi ini kemungkinan dipengaruhi dari komposisi daun kayumanis, sedangkan aktivitas daun sukun sendiri relatif lebih rendah dibandingkan dengan daun herbal lainnya. Ada hal menarik yang diperlihatkan dalam Tabel.1 mengenai efek komposisi formulasi daun herbal terhadap aktivitas antidiabetes. Dari tabel tersebut terlihat aktivitas antidiabetes masing masing herbal, meskipun masing masing herbal memiliki aktivitas antidiabetes yang cukup tinggi, namun pada saat diformulasikan belum tentu memiliki aktivitas yang sama tingginya. Hal ini terkait dengan sinergis aktivitas antar 
Pengaruh komposisi herbal dalam minuman teh hijau gambung herbal terhadap hambatan $\alpha$ glukosidase

herbal itu sendiri.Ada herbal yang saling sinergis dalam menghasilkan aktivitas antidiabetes yang bagus dan ada juga yang sebaliknya.

Data aktivitas antidiabetes masing masing herbal dan formulasi teh hijau gamboeng herbal dapat dibandingkan pula dengan aktivitas EGCG sebagai standar. Dimana EGCG telah dilaporkan memiliki aktivita antidiabetes yang cukup baik, EGCG sebagai kontrol positif memiliki persen hambatansebesar $89 \% .^{15}$

Dalam data toksisitas awal, semua ekstrak air herbal pada konsentrasi $1 \%$ tidak memperlihatkan adanya kematian larva udang yang sudah di kembang biakan selama $3 \times 24$ jam. Daun salam dan daun sawo pada konsentrasi $2 \%$ tidak memperlihatkan adanya kematian larva udang, sedang kan daun kayumanis memperlihatkan adanya kematian sebesar 5 ekor larva udang yang mati. Pada konsentrasi $5 \%$, hanya daun sukun, dauhn the hijau gambung dan daun sawo tidak memperlihatkan adanya kematian larva udang, pada teh hijau gambung, daun kayumanis, daun salam memperlihatkan kematian dari semua larva udang pada konsentrasi $10 \%$ dan $15 \%$ sedangkan pada daun sukun memperlihatkan kematian dari 37 larva udang yang di ternakkan. Sedangkan pada daun sawo tidak memperlihatkan adanya kematian. Ini menandakan semakin besar konsentrasi seduhan, semakin kental ekstrak herbal menyebabkan kematian pada larva udang, berbanding terbalik dengan seduhan yang mempunyai konsentrasi kecil.

Pada formula konsentrasi yang dipakai adalah konsentrasi kecil, untuk formula

THG-AwK,THG-Un-K, THG-Am-K tidak memperlihatkan adanya kematian larva udang. Ini menandakan formula yang dibuat dikategorikan aman dikonsumsi.

\section{KESIMPULAN}

Formulasi teh hijau gambung herbal yang diperkaya dengan daun sukun (Artocarpus communis(Un)), daun salam (Syzygium polyanthum $(\mathrm{Am})$ ), daun kayumanis (Cinnamomum verum), dan daun sawo (Manilkara zapota (Aw)) memperlihatkan hambatan optimum pada konsentrasi pada $10 \%$ untuk daun gambung, daun salam dan daun sawo, sedangkan untuk formulasi dilakukan pada konsentrasi $1 \%$ dikarenakan setelah dilakukan uji praklinis awal, pada konsentrasi $1 \%$ tidak memperlihatkan adanya kematian larva, maka dibuatlah formula dengan konsentrasi tersebut. 
Pengaruh komposisi herbal dalam minuman teh hijau gambung herbal terhadap hambatan $\alpha$ glukosidase

Hambatan enzim a-glukosidase dari formula THGKS $S_{k}$ (96.29\%) lebih tinggi dibandingkan THGKS $S_{w}(62.48 \%)$ dan THGKSI(94.78\%).

\section{DAFTAR PUSTAKA}

1. Ajisaka. Teh Dahsyat Khasiatnya, VI-VIII, Stomata. Surabaya: 2012. hal 1 dan 28.

2. Johnson R, Bryant $S$, Alyson $L$, and Huntley. Green Tea and Green Tea Catechin Extracts: An overview of the clinical evidence. Maturitas. 2012;73:280-287.

3. Armoskaite $\mathrm{V}$, Ramanauskiene $\mathrm{K}$, Maruska A, Razukas A, Dagilyte A, Baranauskas A and Briedis V. The analysis of quality and antioxidant activity of green tea extracts. Journal of Medicinal Plants Research. 2011;5(5): 811-816.

4. Sutarna $T H$, Ngadeni A dan Anggiani R. Formulasi sediaan Masker Gel dari ekstrak etanol daun teh hijau (Camelia Sinensis L dan madu hitam (Apidorsata) sebagai antioksidan. Jurnal IImia Farmasi. 2013;1(1).

5. Rohdiana D. Keunggulan Polifenol teh. Food Review. 2012;7(7):44-47.

6. Brannon C. Green Tea: New benefits from an Old favorite Nutrition Dimention Inc., 2012. www.nutritiondimention.com. $\mathrm{DOI}=10.1 .1 .529 .2116 \& \mathrm{rep}=$ rep $1 \&$ ty $\mathrm{pe}=\mathrm{pdf}$

7. Alipoor B and Rad AH. A Review On The Therapeutical Effects Of Tea. Asian Journal of Clinical Nutrition. 2012;4:1-15.
8. Jayasekera S, Kaur L, Molan AL, Garg ML, Moughan PJ. Effects of season and plantation on phenolic content of unfermented and fermented Sri Lankan tea. Food Chem. 2014;152:546-551.

9. Lotulung PDN, Fajriah S, Sundowo $A$ and Filaila E. Anti diabetic Flavanone Compound From The Leaves Of Artocarpus communis. Indosian Journal of Chemistry.2009;9(3):466-469.

10.Sakka L. Uji Efek Anti diare Seduhan KayuManis (Cinnamomum zeylanicum BI.) pada Mencit Jantan (Mus musculus). Journal of Pharmaceutical Science and Herbal Technology. 2016;1(1):19-22.

11. Bahriul $\mathrm{P}$, Rahman $\mathrm{N}$ dan Diah AWM. Antioxidant Activity Test of Bay Leave (Syzygium polyanthum) Extract Using 1,1-diphenyl-2picrilhidrazyl. J. Akad. Kim.2014; 3(3): 143-149.

12. Rahman $S$ dan Wati A. Uji Efek Hipoglikemik Ekstrak Etanol Buah Sawo Manila (Manilkara zapota) Pada Mencit Jantan Yang Dinduksi Aloksan. As-Syifaa.2016;08(01):7681.

13. Dewi RT, Darmawan A, Mulyani H, Lotulung PDN, Minarti and Megawati. a-Glucosidase Inhibitory Effect Of Sulochrin From Aspergillus and Its brominated Derivatives. Malaysia Journal of Science. 2018;37(1):70-81.

14. Megawati, Saepudin E, Hanafi M, Darmawan A and Lotulung PDN. Identification and Bioactivity Studies of Flavonoid Compounds from Macaranga hispida (Blume) Mull. 
Pengaruh komposisi herbal dalam minuman teh hijau gambung herbal terhadap hambatan $\alpha$ glukosidase

Arg. Makara Jounal. Sci. 2015;19(3):96-100.

16. Yashin A, Yashin $Y$ and Nemzer B. Determination of Antioxidant Activity

15. Tadera $\mathrm{K}$, Minami $\mathrm{Y}$, Takamatsu $\mathrm{K}$ and Matsuoka. Inhibition of a-Glukosidase and $\alpha$-Amylase by Flavonoids. J Nutr Sci Vitaminol. 2006;52:149-153. in Tea Extracts, and Their Total Antioxidant. Content. American Journal of Biomedical Sciences. 2011;3(4):322-335. 